\title{
Analytic Hierarchy Process Analysis for Industrial Application of LNG Bunkering: A Comparison of Japan and South Korea
}

\author{
Young-Gyu Lee ${ }^{1}$, Jong-Kwan Kim ${ }^{2}$ iD and Chang-Hee Lee ${ }^{3, *(D)}$ \\ 1 Daewoo Shipbuilding \& Marine Engineering Co., Ltd.: DSME, 3370, Geoje-daero, Geoje-si 53302, \\ Gyeongsangnam-do, Korea; yg5004@dsme.co.kr \\ 2 Korea Institute of Maritime and Fisheries Technology, 93 Sinseon-ro 367, Haeyang-ro, Yeongdo-gu, \\ Busan 49111, Korea; jkkim@seaman.or.kr \\ 3 College of Maritime Sciences, Korea Maritime \& Ocean University, Taejong-ro, Yeongdo-gu, \\ Busan 49112, Korea \\ * Correspondence: chlee@kmou.ac.kr; Tel.: +82-010-8577-8618 or +82-510-410-4642; Fax: +82-051-404-3985
}

check for updates

Citation: Lee, Y.-G.; Kim, J.-K.; Lee, C.-H. Analytic Hierarchy Process Analysis for Industrial Application of LNG Bunkering: A Comparison of Japan and South Korea. Energies 2021, 14, 2965. https://doi.org/10.3390/ en14102965

Academic Editor: Fabio Polonara

Received: 2 April 2021

Accepted: 7 May 2021

Published: 20 May 2021

Publisher's Note: MDPI stays neutral with regard to jurisdictional claims in published maps and institutional affiliations.

Copyright: (c) 2021 by the authors. Licensee MDPI, Basel, Switzerland. This article is an open access article distributed under the terms and conditions of the Creative Commons Attribution (CC BY) license (https:/ / creativecommons.org/licenses/by/ $4.0 /)$.

\begin{abstract}
From January 2020, the International Maritime Organization has regulated ship emissions to reduce sulfur content. As an alternative to this, LNG bunkering was proposed, and infrastructure and ships were deployed. Therefore, we used analytic hierarchy process AHP techniques to determine optimal methods of LNG bunkering for shipyard safety. First, we conducted a literature survey on the concept and type of LNG bunkering, global LNG bunkering trends, and features of Japan and South Korea cases and compared them. Thereafter, an expert survey was conducted, and survey data was analyzed using AHP techniques. Finally, we derived optimal methods applicable to shipyard industry. The analytical results revealed that the derived priority of the optimal LNG bunkering method of shipyard was in the order of the STS method, TTS method, and the PTS method. The result of this study can serve as a theoretical basis to make LNG bunkering safer and more economical in shipyards to prepare for the expansion of demand of LNG-fueled ships and LNG. However, this study inevitably has limitations of ranking reversals paradox as it was conducted by experts, assuming no weights to STS, TTS, or PTS.
\end{abstract}

Keywords: LNG; international maritime organization; LNG bunkering; shipyard; analytic hierarchy process

\section{Introduction}

With increasing severity of climate change caused by global warming, discussions on minimizing the risk of pollution from shipping and port-related environmental impacts [1,2] are increasing. In particular, International Maritime Organization (IMO) Tier III, Chapter VI, Annex of the International Convention for the Prevention of Pollution from Ships (MARPOL 73/78), a standard on emission limits of nitrogen oxide (NOx) and sulfur oxide (SOx) from ships, entered in force in 2010 and was applied to all new ships from 2016. Moreover, in October 2016, with IMO announcing that it would apply more stringent regulations on GHG emissions from ships in all seas from 2020, the global shipbuilding/shipping/port industries have reviewed various alternatives, such as the use of marine fuels with low sulfur content, replacement with LNG fuel, and installation of a scrubber for responsive measures and compliance with the new regulations [3]. In the case of marine diesel engines, the emission of air pollutants such as NOx, SOx, CO, and $\mathrm{CO}_{2}$ from heavy fuel oil containing asphalt, carbon residues, sulfur, and metal compounds inevitably arises during combustion [4]. Among alternative measures, LNG-fueled ships are drawing attention as an economical and efficient feasible alternative [5]. In this regard, global shipping companies such as CMA-CGM and NYK are actively considering the adoption of LNG carriers when ordering new ships, and shipbuilding and related equipment 
industries have increased their investments in the development of high fuel-efficiency and technology to reduce air pollution from ships [6].

When LNG-fueled ships are fully implemented, the LNG bunkering industry should also be developed, such as establishing an infrastructure for filling LNG as fuel and building ships for LNG bunkering. Therefore, infrastructure related to LNG bunkering has already been built in regions such as the Port of Rotterdam in the Netherlands, Port of Antwerp and Port of Zeebrugge in Belgium, Port of Jacksonville in the United States, and Port of Yokohama in Japan, and LNG bunkering ships required for LNG-fueled ships have already been deployed for operation [7]. However, in South Korea, commercial offshore LNG bunkering has not been carried out in practice, but there are cases of its limited implementation, such as (1) LNG bunkering at the level of government and public agencies, (2) design, shipbuilding, and demonstration projects of LNG bunkering ships for R\&D purposes, and (3) pilot-type LNG bunkering of the truck to ship (TTS) method and LNG transfer operation of the ship to ship (STS) method in shipyards.

In particular, domestic shipbuilding industries have increased investments for R\&D in the design of LNG, hydrogen, ammonia-fueled ships, and maritime autonomous surface ships (MASS), but failed to prepare themselves for the demand of LNG, hydrogen, ammonia-fueled ship likely to be increased in the future. So, we tried to derive LNG bunkering methods suitable for each shipyard situation based on the analytic hierarchy process (AHP) method. Therefore, to determine the optimal commercial LNG bunkering method in South Korea, LNG bunkering, currently operated in a shipyard, was selected as the subject of this study. In addition, we developed a reference standard to facilitate objective decision-making using AHP, and based on the analysis, we aimed to design an LNG bunkering arrangement diagram in the shipyard " $\mathrm{D}$ " as an illustrative case in consideration of relative importance and priority of the optimal LNG bunkering method. Global shipbuilding industries can make decisions using AHP method derived from the result of this study, which can serve as a theoretical basis to ensure safe and economical LNG bunkering in the shipyards to prepare for the increased demand of LNG-fueled ships and LNG carriers. The research outline of the current study based on AHP is illustrated in Figure 1.
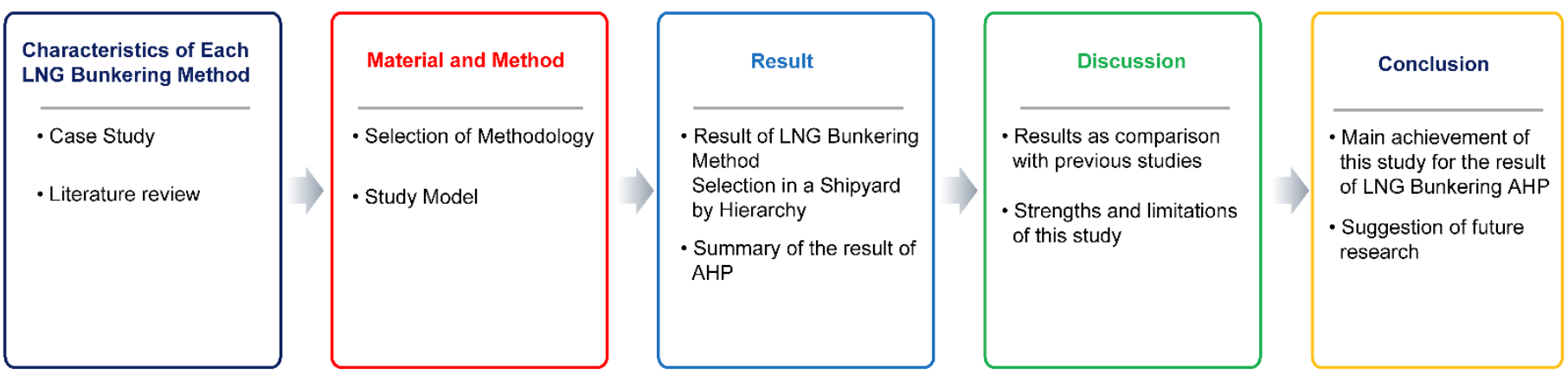

Figure 1. Outline of the research.

\section{LNG Bunkering Methods and Successful Applications}

In the STS method, LNG bunkering from an LNG bunkering ship to an LNG-fueled ship is achieved, as shown in Figure 2a. LNG bunkering ships perform the role of bunkering LNG to LNG-fueled ships with its direct transfer from an offshore floating LNG bunkering terminal (FLBT) or an onshore LNG storage tank with a terminal [8]. In particular, this method is advantageous in terms of the fast LNG bunkering speed and large-capacity supply. However, its disadvantage is high initial investment various purposes, such as building of an LNG bunkering ship and LNG storage tank with a terminal [9]. 


\section{(a) Ship to ship method}

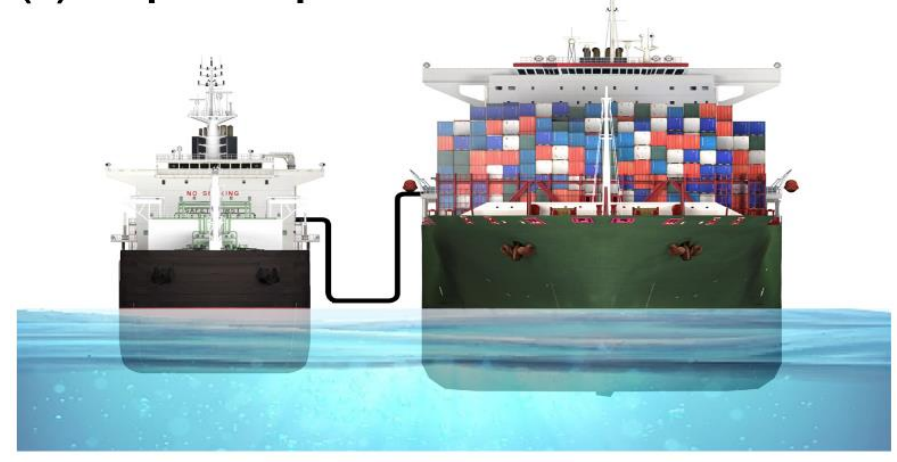

\section{(b) Truck to ship method}

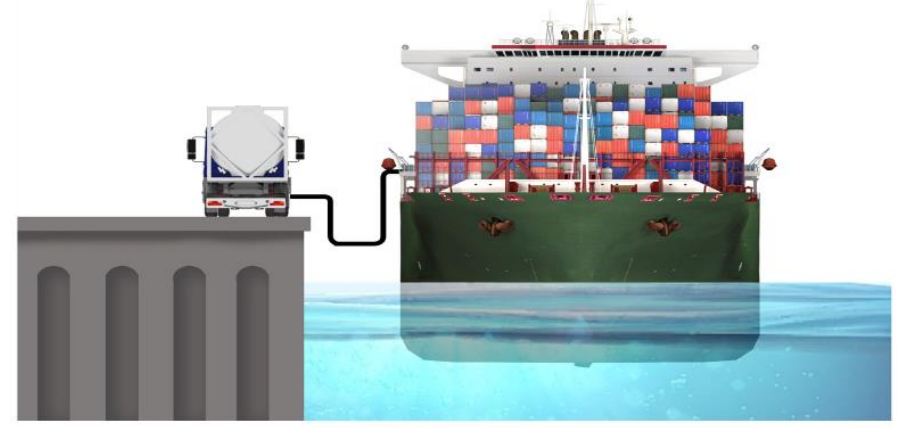

(c) Pipe to ship method

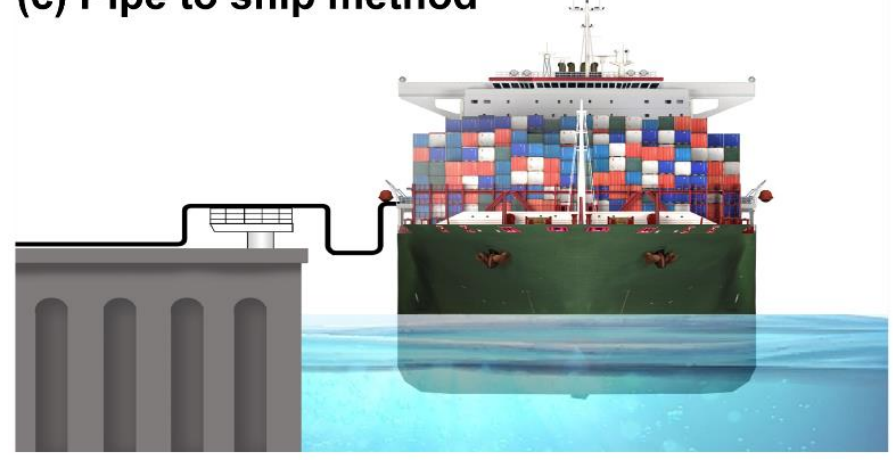

Figure 2. LNG Bunkering methods: (a) ship to ship method, (b) truck to ship method, and (c) pipe to ship method.

On the contrary, the TTS method achieves bunkering from an LNG tank lorry truck to an LNG-fueled ship, and this method is mainly effective for small-capacity LNG bunkering, as shown in Figure 2b. Therefore, this method is primarily used to develop a small-capacity LNG bunkering facility or supply LNG to small LNG-fueled ships before establishing a full-scale LNG bunkering infrastructure through an LNG fuel storage base at the port. Therefore, compared to the STS method, this method does not require large amounts of funds or time to build the infrastructure initially required for LNG bunkering, and it has the advantage of flexible bunkering using a mobile facility called an LNG storage truck. However, the TTS method is not suitable for LNG bunkering for large commercial ships due to low bunkering capacity and speed [10].

The pipeline to ship (PTS) method achieves bunkering using a bunkering pipeline or loading arm and by berthing an LNG-fueled ship to a dedicated LNG terminal installed onshore or offshore. Finally, this method has the advantage of ensuring large capacity, speed, and safety related to LNG bunkering as shown in Figure 2b, and thus it is a useful when constructing a new port or expansion of a port in the future. However, this method is vulnerable to natural disasters, such as earthquakes and tsunamis, and requires 
considerable initial investment cost and time, such as that for the construction of dedicated facilities for LNG bunkering, berthing, and mooring facilities onshore and offshore [7].

\subsection{First Successful Cases of LNG Bunkering in Japan and South Korea in 2020}

\subsubsection{Japan}

In 2012, Japan founded a general committee for the promotion of LNG bunkering ships centering on the Ministry of Land, Infrastructure, Transport and Tourism (MLIT) and developed standard guidelines and an operation manual setting safety measures when supplying LNG fuel to ships. Design guidelines for high-pressure gas supply systems were also proposed, thereby laying the foundation for the commercialization of LNG bunkering [11]. Thereafter, by promoting advanced ships in Chapter 6 of the Maritime Transport Act in October 2017, Japan established a legal basis for fiscal support for the construction cost of LNG bunkering ships and facilities of LNG fuel supply to LNG bunkering ships and completed an institutional foundation for commercialization [12].

Examining a real case example, in October 2020, LNG bunkering from an LNG bunkering ship "KAGUYA" (specifications outlined in Table 1) to "SAKURA LEADER" (an automobile carrier) was successfully conducted using the STS method for the first time in Japan. As shown in Figure 3, this success could be attributed to development of win-win LNG bunkering cluster including support of construction cost for "KAGUYA" on the level of MLIT, Japan and LNG purchase from private thermal power plants, willingness to accept LNG fuel supply contract of NYK, one of the shipping companies in Japan, incentive provision of exemption of port entrance fee for LNG-fueled ships and LNG bunkering ships by Nagoya port bureau, and cooperation on obtaining permissions for handling various hazardous substances. However, Japan also has limitations in that it is yet to develop separate guidelines for optimized LNG bunkering by considering characteristics of each port. It only conducts LNG bunkering according to the demand and supply of LNG bunkering.

Table 1. Specifications of KAGUYA, an LNG bunkering carrier in Japan.

\begin{tabular}{ccccc}
\hline Shipyard & $\begin{array}{c}\text { Loading } \\
\text { Capacity }\end{array}$ & $\begin{array}{c}\text { Gross } \\
\text { Tonnage }\end{array}$ & $\begin{array}{c}\text { Length } \\
\text { Overall }\end{array}$ & Beam \\
\hline $\begin{array}{c}\text { Kawasaki Heavy Industries, Ltd., } \\
\text { Sakaide Works }\end{array}$ & $3500 \mathrm{~m}^{3}$ & $4044 \mathrm{GT}$ & $81.7 \mathrm{~m}$ & $18 \mathrm{~m}$ \\
\hline
\end{tabular}

Source: https:/ / www.marinetraffic.com/en/ais/details/ships/shipid:6347651/mmsi:431015687/imo:986229 3/vessel:KAGUYA (accessed on 31 January 2021) [13].

\subsubsection{South Korea}

Although South Korea has built several LNG ships in global shipyards, such as those of Hyundai Heavy Industries (Bangeojinsunhwan-doro, Dong-gu, Ulsan, 44032, Korea), Samsung Heavy Industries (Pangyo-ro 227beon-gil, Bundang-gu, Seongnam-si, Gyeonggi-do 13486 Korea) and Daewoo Shipbuilding \& Marine Engineering Co., Ltd. (DSME) (Geojedaero, Geoje-si, Gyeongsangnam-do 53302 Korea), the Korean government and shipping companies have been relatively behind in terms of technology development and R\&D investment for LNG-fueled and LNG bunkering ships [15]. However, the Ministry of Oceans and Fisheries recognized the necessity of introducing eco-friendly ships in preparation for IMO 2020, and ECONURI (Incheon Port Authority, 260-ton port guiding ship) in 2013, Green IRIS (Ilshin Marine Transport Co. Ltd. (Pohang; Gyeongsangbuk; 791130 Korea), a 50,000-ton bulk carrier) in 2017, and Cheonghwa 2 (Korea Marine Environment Management Corporation, a 230-ton oil clean-up vessel) in 2018, were launched for operation through small-scale contracts of some public agencies and long-term contracts of private companies with a specific shipper [16]. In addition, to implement the Green New Deal policy of the South Korean government for expanding the development of LNG-fueled and LNG bunkering ship industry, South Korea benchmarked Japanese cases and enacted the Act on Promotion of Development and Distribution of Environment-Friendly Ships on 31 
December 2018. This act provided a basis for the establishment of a basic and development plan for the construction of LNG bunkering infrastructure necessary for supply of ship fuel, support for related technology development and for ship owners and eco-friendly fuel producers, thereby establishing a foundation for the active promotion of the LNG bunkering industry [17].


\section{ship operation}

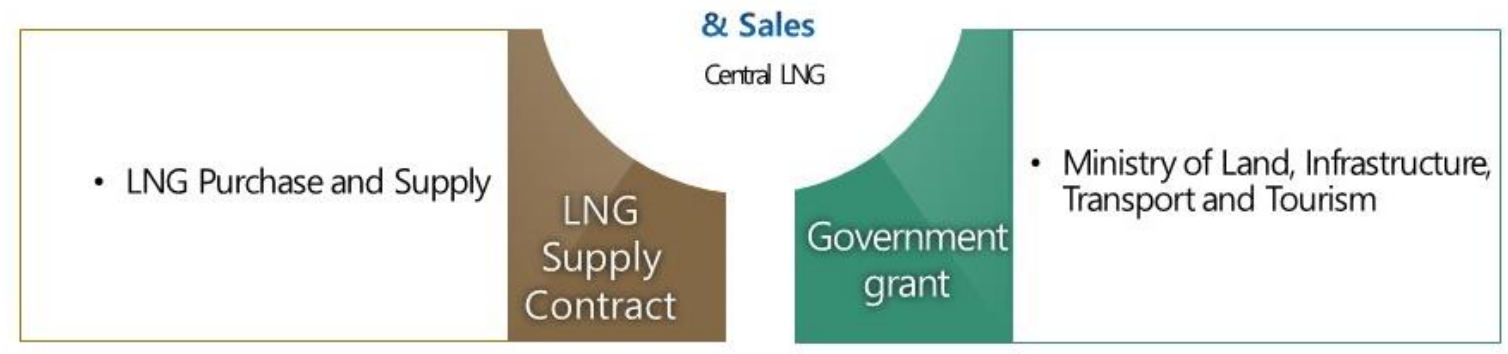

Figure 3. LNG bunkering ship operation chain in Japan. Source: Re-edited by author based on data from https:/ / centrallng.com/en/ (accessed on 31 January 2021) [14].

As a result of these efforts, an empirical test of LNG transfer of volume of $4000 \mathrm{~m}^{3}$ between an LNG bunkering tanker "SM JEJU 2" with the specifications shown in Table 2 and "GLOBAL STAR", a ship owned by Maran Gas, Greece, under construction at DSME, was successfully conducted on 26 November 2020 using the STS method for the first time in a shipyard. Compared to the case in Japan, it is not a real LNG fuel STS for ships in commercial operation, but it is significant in that the test was successful without incidents of leaks, fires, or explosions in a special quay environment of a shipyard $[18,19]$. However, in terms of location, this test was conducted in a specific quay within a shipyard, not in the port, and strictly speaking, only LNG transfer was achieved and not LNG fuel supply. However, this case is thought as the stepping stone for the development of a bunkering cluster, similar to the case of Japan, in that there was mutual cooperation among multiple areas such as risk analysis, development of procedures, installation of equipment, work of berthing or unberthing of a ship between Korea Gas Corporation, Korean Register of Shipping, DSME, and SM Korea Line Co., Ltd., to address problems of technical, environmental, and safety factors in a shipyard. Nevertheless, this case has a limitation in terms of expanding its application to other places, including other shipyards, due to insufficient basic scientific research on LNG bunkering for a shipyard quay.

Table 2. Specifications of SM JEJU 2, an LNG bunkering combined carrier in South Korea.

\begin{tabular}{lllcc}
\hline \multicolumn{1}{c}{ Shipyard } & $\begin{array}{l}\text { Loading } \\
\text { Capacity }\end{array}$ & $\begin{array}{c}\text { Gross } \\
\text { Tonnage }\end{array}$ & $\begin{array}{c}\text { Length } \\
\text { Overall }\end{array}$ & Beam \\
\hline SAMSUNG Heavy Industry & $7500 \mathrm{~m}^{3}$ & $9370 \mathrm{GT}$ & $97 \mathrm{~m}$ & $22 \mathrm{~m}$ \\
\hline $\begin{array}{l}\text { Source: https://wWw.vesselfinder.com/vessels/SM-JEJU-LNG2-IMO-9830757-MMSI-374333000 (accessed on 31 } \\
\text { January 2021) [20]. }\end{array}$ & & &
\end{tabular}


As for representative reasons for limitations in LNG fuel supply in commercial applications in South Korea, the dominant opinion is that the LNG bunkering cluster, as in the case of Japan, was not properly developed. Indeed, from the perspective of the consumer, such as ship owners, without information on when LNG supply will be available or whether the LNG supply price will be competitive compared to that of the existing fuel, making investments to renovate an existing ship or build a new ship with confirmed decision-making for the future is difficult. In addition, from the perspective of the South Korean government or LNG suppliers such as the Korea Gas Corporation, it is also considerably difficult to invest in expanding LNG storage tanks with terminals in specific ports when the future demand of LNG as ship fuel cannot be predicted [19]. In the end, without developed bunkering clusters, the consumer and the supplier are hesitant to invest first because of uncertain factors, and thus, the LNG bunkering market in South Korea is currently in a stalemate. Therefore, to resolve these problems, the South Korean government, shipping companies, shipyards, marine equipment companies, universities, and research institutes should take preemptive and collaborative approaches for regulatory and technical problems, as well as the problem of developing demand in terms of promoting the introduction of LNG-fueled ships, capacity building for building LNG-fueled ships, expansion of operational base of LNG-fueled ships, and development of international collaborative networks. This will enable development and establishment of policies for the promotion of LNG bunkering business as a top priority.

\subsection{Literature Review}

In several previous studies, various insights into LNG bunkering with IMO 2020, operation procedures, risk assessment and management, technology utilization, policy and regulation, and AHP were provided. For example, regarding research on IMO 2020 related to LNG bunkering, Byrnes et al. [1] presented an overview of the government- and industry-related actions relevant to covering various environmental impacts associated with the commercial, industrial, and recreational shipping industries. Winnes et al. [3] concluded that a scrubber can remove $32-43 \%$ of the particle mass from the exhaust gas. Lim [6] stated that global shipping companies can strategically choose LNG as a ship fuel for replacing HFO from an echo-friendly perspective.

With respect to research on LNG bunkering operation procedures, Laribi et al. [21] found that based on an LNG-fueled ship, LNG has the potential for future growth, and they planned to expand LNG bunkering infrastructure in European ports. Park et al. [7] proposed a method for estimating the size of LNG facilities required for LNG bunkering demand and supply in Busan Port in Korea. Kim et al. [22] emphasized that the major issue of LNG bunkering vessels (LNGBVs) is the mismanagement of boil-off gas generated during loading and unloading processes. Sun et al. [23] emphasized that the numerical simulations of full-scale ship self-propulsion show good agreement with sea trail data, especially for actual testing.

As for research on LNG bunkering risk assessment and management, Chun et al. [16] found that key issues for LNG are related to fuel as ships in bunkering and storing. Lee and Nam [15] found that boil-off gas management is more difficult than normal BOG management due to parametric influences on vapor generation. Xuan et al. [24] provided a systematic literature review of the risk factors and intrinsic relationship in LNG operation. Vidmar et al. [25] highlighted that dangerous cargo accidents in exclusive terminals result in catastrophic disasters.

With respect to research on LNG bunkering technology utilization, Lee and Nam [15] recommended enhancing strategic countermeasures in preparation for shipping-shipbuilding correlative networks to build eco-friendly vessels and to support LNG-fueled ships. They concluded that a pile-guide mooring system was essential for LNG-fueled ships.

Regarding research on LNG bunkering policy and regulation, Lee and Woo [17] found that the Green New Deal policy included three strategic areas: low-carbon, green urban, and green energies. Ung et al. [12] suggested various insights into the LNG bunkering 
regulation scheme in China and Japan and founded the legislative and normative rules of these countries regarding the maritime industry.

Finally, as for research on the AHP approach and its application, Sánchez-Lozano et al. [26] found that the AHP approach is applied to set out the weights of the criteria, while the TOPSIS method provides a ranking of alternatives to achieve prioritization. Mackinnon [27] defined the potential applications for the successive, proportionate, additive numeration (SPAN) technique and presented a hypothetical case in which SPAN serves as a weighting in organization. Hong et al. [28] suggested impact factors by surveying and brainstorming and calculated their weights using AHP to evaluate alternatives for supplying liquefied natural gas. The authors concluded that AHP is a useful method for evaluating multi-criteria decision-making problems. Saaty [29] recommended a method of scaling ratios using the principal eigenvector of a positive pairwise comparison matrix.

While many studies have covered LNG bunkering-related IMO 2020, risks, operation procedures, risk assessment and management, technology utilization, policy and regulation, and AHP approach and application, basic research to determine the optimal commercial LNG bunkering measures in South Korea is lacking; thus, LNG bunkering, which is currently in operation in a shipyard, was selected as the subject of this study.

\section{Materials and Methods}

\subsection{Selection of Methodology}

The multi-criteria decision-making method (MCDM) includes the ordinal method and the cardinal method. Among the cardinal methods, the relative importance is provided by the evaluating subject, and all evaluators simplify the relative importance of each evaluation criterion. The weighted scoring method that evaluates carefully, the technique for order performance by similarity to ideal solution (TOPSIS) method, prioritizes higher priority when the evaluation target is closer to the ideally considered alternative and farther from the worst choice, The AHP method prioritizes alternatives by collecting pairwise comparative evaluation data as group opinions, and successive proportional additive numeration (SPAN) allows evaluators with expertise to delegate some of their assigned scores to other evaluators [30]. Among them, the AHP method is a method designed for multi-faceted evaluation criteria and decision-making by multiple actors for multiple alternatives. By considering both quantitative and qualitative factors based on the intuitive, rational, or irrational judgments of the decision maker, it has the advantage of providing a comprehensive framework for solving decision-making problems, and the SPAN method focuses on the fact that are differences in professional knowledge between evaluators, and those who know these differences best are experts in the same field. MacKinnon [31] is a method to reflect the difference in judgment among experts. Among the decision-making methodologies, the practical characteristics of the AHP methodology, which are suitable for solving the problem of taking complex and ambiguous decisions, have increased applicability to a wide variety of fields and studied extensively. When AHP is used to solve a problem related to decision-making, the process generally consists of the following four steps. First, a decision-making hierarchy is established by decomposing the decision-making problem into hierarchies of interrelated decision-making elements. The model has at least three hierarchies. The purpose for problem solving is placed at the top, multiple criteria for selecting alternatives in the middle, and alternatives at the bottom [30]. This process is the most important step in the AHP methodology, and the analyst should decompose the decision-making problem into interrelated elements for decision-making [29].

In the second step, data for decision-making are collected using a pairwise comparison method comparing only two decision elements at a time. Regardless of whether each criterion or alternative is specific, expert decisions on relative importance should be made through this pairwise comparison, which is done here using a 9-point scale. 
The result of the pairwise comparison has the following vector shape with the diagonal value equal to Equation (1).

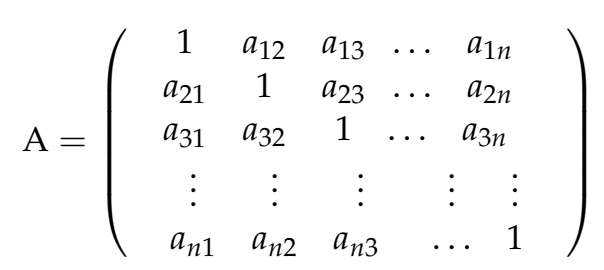

This part is expressed as $a_{i j}=1 / a_{j i}, a_{i i}=1$.

The third order uses the eigenvalue method to relatively estimate the weights of the decision factors. If the relative importance of ' $n$ ' factors to be compared in the hierarchy is $w_{1}(\mathrm{i}=1, \ldots, n)$ then $a_{i j}$ can be estimated as $w_{i} / w_{j}(i, j=1, \ldots, n)$ in the comparison matrix. Accordingly, the following Equation (2) is established.

$$
a_{i j}=w_{i} / w_{j}(i, j=1, \ldots, n)
$$

All the elements of the matrix accordingly can be expressed as Equation (3).

$$
\sum_{j}^{n} a_{i j} \cdot w_{j} \cdot \frac{1}{w_{i}}=n(i, j=1, \ldots, n)
$$

It can be simplified as Equation (4).

$$
\sum_{j}^{n} a_{i j} \cdot w_{j}=n \cdot w_{j}(i, j=1, \ldots, n)
$$

The above equation is the same as the eigenvalue problem solution in linear algebra. The ' $\mathrm{A}$ ' matrix composed of elements $a_{i j}$ can be expressed by the following equation,

$$
\mathbf{A}=\left(\begin{array}{ccccc}
w_{1} / w_{1} & w_{1} / w_{2} & w_{1} / w_{3} & \ldots & w_{1} / w_{n} \\
w_{2} / w_{1} & w_{2} / w_{2} & w_{2} / w_{3} & \ldots & w_{2} / w_{n} \\
w_{3} / w_{1} & w_{3} / w_{2} & w_{3} / w_{3} & \ldots & w_{3} / w_{n} \\
\vdots & \vdots & \vdots & \vdots & \vdots \\
w_{n} / w_{1} & w_{n} / w_{2} & w_{n} / w_{3} & \ldots & w_{n} / w_{n}
\end{array}\right)
$$

The above equation is expressed by the eigenvalue method as follows.

$$
A \cdot w=n \cdot w
$$

$w$ is the right eigenvector of matrix $A$, and $n$ is the eigenvalue of matrix $A$. Using the above equation, $w$ can be obtained. The method to find the $w$ for each element of the pairwise comparison matrix $A$ is as follows. If the matrix obtained through the questionnaire is $A \prime$ and $w /$ is the weight of this matrix, the following equation is established.

$$
A^{\prime} \cdot w^{\prime}=\lambda_{\max } \cdot w^{\prime}\left(\lambda_{\max }: \text { Largest eigenvalue of matrix } A^{\prime}\right)
$$

The important aspect to note in the third step is the verification of consistency. In the AHP method, to verify the reliability of the analysis data, a consistency index (CI) and a consistency ratio (CR), which indicate the degree of error in decision-making, are obtained. If CR is less than 0.1 , the pairwise comparison is judged to be reasonably consistent. CR can be measured from CI and the random index (RI), and can be derived using Equations (8) and (9).

$$
\text { Consistency Index }(C I)=\frac{\left(\lambda_{\max }-n\right)}{(n-1)}
$$




$$
\text { Consistency Ratio }(\mathrm{CR})=\frac{C I}{R I} \times 100 \%
$$

In addition, as shown in Table 3, RI was calculated by averaging the CI of a matrix. RI is a value obtained by selecting numbers from 1 to 9 at random to create an inverse matrix and averaging the CI for this matrix, which is the allowable limit of consistency. This is also referred to as the mean RI.

Table 3. Random Consistency Index.

\begin{tabular}{ccccccccccc}
\hline $\boldsymbol{n}$ & $\mathbf{1}$ & $\mathbf{2}$ & $\mathbf{3}$ & $\mathbf{4}$ & $\mathbf{5}$ & $\mathbf{6}$ & $\mathbf{7}$ & $\mathbf{8}$ & $\mathbf{9}$ & $\mathbf{1 0}$ \\
\hline$R I$ & 0 & 0 & 0.58 & 0.90 & 1.12 & 1.24 & 1.32 & 1.41 & 1.45 & 1.49 \\
\hline
\end{tabular}

In the last step, a ranking that comprehensively considers the opinions of the group for the proposed alternatives should be indicated. To draw a conclusion, three methods are used to indicate the score by synthesizing the relative weights of the elements in the hierarchy. The first method is a single pairwise comparison method, where, for each value of the pairwise comparison matrix evaluated by the survey respondents, the geometric mean is taken for the evaluation values of all the participating evaluators for synthesis of the values, and the result is used as the measurement value. The second method obtains synthesized weights by calculating the arithmetic mean of the eigenvector values of the survey respondents, and the final method involves synthesizing the values by obtaining the geometric mean of the eigenvector values. There was no significant difference in the results obtained using the above three methods.

\subsection{Study Model}

The decision-making structure of this study is divided into three hierarchies for analysis, as shown in Figure 4. The purpose of the survey was the "determination of the LNG bunkering method in the shipyard using $\mathrm{AHP}^{\prime \prime}$, and major factors influencing the preference of the set type were classified into three categories, as shown in Table 4 . These were "technical factors" in which accumulated core technologies and application technologies act as key factors, "environmental factors" in which factors of external environment are more important than technology, and "safety factors" in which risk factor elimination and emergency response are considered more important than technology and environment.



Figure 4. AHP framework for optimal LNG bunkering model in shipyard. 
Table 4. Classification and description on decision-making hierarchy of LNG bunkering method selection in a shipyard.

\begin{tabular}{|c|c|c|c|c|}
\hline Category & & Title & Description & Remark \\
\hline \multirow{9}{*}{ Hierarchy } & \multirow{3}{*}{ Technical factor } & Technical excellence & $\begin{array}{l}\text { Equipped with core technologies accumulated } \\
\text { through pilot operation of LNG-fueled ships }\end{array}$ & [32] \\
\hline & & Technical versatility & $\begin{array}{l}\text { Application technologies for LNG bunkering in } \\
\text { shipyard based on cold test and quay pilot operation, } \\
\text { etc. }\end{array}$ & [33] \\
\hline & & Technical reliability & $\begin{array}{l}\text { Equipped with technologies for controlling leaks and } \\
\text { overpressures that may occur during the process of } \\
\text { LNG bunkering }\end{array}$ & [19] \\
\hline & \multirow{3}{*}{$\begin{array}{l}\text { Environmental } \\
\text { factor }\end{array}$} & Quay environment & $\begin{array}{l}\text { Berthing environment between LNG bunkering ship } \\
\text { and LNG-fueled ship or between LNG-fueled ship } \\
\text { and quay in the shipyard }\end{array}$ & [23] \\
\hline & & $\begin{array}{l}\text { Legal/policy } \\
\text { environment }\end{array}$ & $\begin{array}{l}\text { Legal/policy environment in relation to LNG } \\
\text { bunkering }\end{array}$ & [18] \\
\hline & & Demand environment & Annual demand environment for LNG bunkering & [7] \\
\hline & \multirow{3}{*}{ Safety factor } & Risk management & $\begin{array}{l}\text { Management capability for removal of risk factors } \\
\text { around the specific quay and workplace for LNG } \\
\text { bunkering }\end{array}$ & [34] \\
\hline & & Emergency response & $\begin{array}{l}\text { Emergency response in case when a dangerous } \\
\text { situation occurs during the process of LNG } \\
\text { bunkering }\end{array}$ & [24] \\
\hline & & Cooperation & $\begin{array}{l}\text { Communication and cooperation with various } \\
\text { interested parties during the process of LNG } \\
\text { bunkering }\end{array}$ & [25] \\
\hline \multirow{3}{*}{ Alternatives } & \multicolumn{2}{|c|}{ Ship to Ship LNG bunkering } & $\begin{array}{l}\text { STS bunkering is the transfer from one vessel or } \\
\text { barge with LNG as cargo to another vessel for use as } \\
\text { fuel on dock or jetty even anchorage }\end{array}$ & \multirow{3}{*}{ [35] } \\
\hline & \multicolumn{2}{|c|}{ Truck to Ship LNG bunkering } & $\begin{array}{l}\text { TTS bunkering is the transfer of LNG from a truck's } \\
\text { storage tank to a vessel moored to the dock or jetty }\end{array}$ & \\
\hline & \multicolumn{2}{|c|}{ Pipe to Ship LNG bunkering } & $\begin{array}{l}\text { PTS bunkering is the transfer from a fixed storage } \\
\text { tank on land through a cryogenic pipeline or } \\
\text { exclusive loading arm with a flexible end piece or } \\
\text { hose to a vessel moored to a nearby dock or jetty }\end{array}$ & \\
\hline
\end{tabular}

In the sub-criteria, sub-level hierarchies of the technical factor consist of technical excellence, technical versatility, technical reliability, and sub-level hierarchies of the environmental factors consisting of quay, legal/policy, and demand environments. Finally, those of the safety factor consist of risk management, emergency response, and cooperation. Purposes for problem solving are placed at the top, multiple criteria for selecting alternatives in the middle, and alternatives at the bottom [30]. The alternative in this case corresponds to the conclusions of this study. When the hierarchies are derived in sequence, weights are determined through pairwise comparison of the importance of the factors for successful LNG bunkering optimized in the shipyard, and decisions regarding which method is most appropriate are. The alternatives are the three LNG bunkering methods described above. In other words, the proposed methods are as follows: "Ship to Ship LNG bunkering", which supplies fuel by LNG fuel transfer from LNG bunkering ships, "Truck to Ship LNG bunkering", which allows flexible fuel supply for each port using an LNG storage truck, and "Pipe to Ship LNG bunkering" in which LNG is supplied using pipes of small storage tank and loading arms to a dedicated port planned for large-scale LNG fuel supply business.

This survey improved the AHP CI by limiting the options for each hierarchy to three. In particular, in the survey structure, after performing the first and second pairwise 
comparisons, the remaining selection was performed without errors. In addition to the purpose of increasing the CI, questions and response options were clearly prepared to facilitate intuitive derivation of responses considering that theoretical surveys are difficult for field experts in LNG supply.

The subjects of the survey were industrial experts, such as shipyard and ship owners, research experts such as government agencies, shipbuilding and marine research institutes, and registers of shipping, and professors at local universities. In this study, we performed an analysis based on data from the survey using the AHP analysis technique. The subjects were selected from public institutions, research institutes, and companies in the shipbuilding and shipping sectors. In particular, when examining the statistics of the survey respondents, as shown in Table 5, there were 17 experts engaged in industry $(44.7 \%), 13$ in research (34.20\%), and 8 in academia (21.1\%). Regarding years of experience, 9 experts had under 5 years of experience (23.7\%), 14 had $5-10$ years of experience $(36.8 \%)$, 7 had $11-15$ years of experience (18.4\%), and 8 had over 15 years of experience $(21.1 \%)$.

Table 5. Statistics of survey respondents' characteristics.

\begin{tabular}{|c|c|c|c|}
\hline Category & Type & No. of ppl & $\%$ \\
\hline \multirow{2}{*}{ Industry } & Shipyard & 9 & 23.68 \\
\hline & Ship owner & 8 & 21.05 \\
\hline \multirow{3}{*}{ Research } & Government agency & 2 & 5.26 \\
\hline & Research institutes & 8 & 21.05 \\
\hline & Register of Shipping & 3 & 7.89 \\
\hline \multirow[t]{2}{*}{ Academia } & Universities & 8 & 21.05 \\
\hline & Total & 38 & 100.00 \\
\hline \multirow{4}{*}{ Experience } & Less than 5 years & 9 & 23.68 \\
\hline & 5-10 years & 14 & 36.84 \\
\hline & 11-15 years & 7 & 18.42 \\
\hline & More than 15 years & 8 & 21.05 \\
\hline
\end{tabular}

\section{Results}

The results of the AHP analysis for selecting LNG bunkering method in the shipyard are shown in Table 6, and the results for each hierarchy are as follows. First, for the major factor, the technical factor (0.512) was analyzed to have the highest priority, followed by safety (0.269) and environmental (0.219). In Korea, the development and application of LNG bunkering-related technologies are actively underway, and it is crucial to construct an empirical test bed through government-level support and verify safety through technical support. In this context, it can be easily expected that technical factors have high weights, which were verified quantitatively through a survey of related industry experts. However, although LNG has the advantages of being colorless, odorless, non-toxic, and non-corrosive, there are risks of flammability, brittle destruction, and fire and explosion when it is combusted in the gaseous state; thus, emergency responses, including safety factors such as integrated safety management are thought to be imperative. However, it is still an unexpected result that these safety factors are equally similar important as environmental factors. Given these results, it is judged that the technical factor was recognized as the top priority by experts due to the local characteristics of the shipyard and impact of the new technology, LNG bunkering. 
Table 6. AHP analysis result on the selection of LNG bunkering method in a shipyard.

\begin{tabular}{|c|c|c|c|c|c|c|c|c|c|c|}
\hline Major Factor & Weight & Rank & Sub-Criteria & Weight & Rank & $\begin{array}{c}\text { Total } \\
\text { Weight }\end{array}$ & $\begin{array}{l}\text { Total } \\
\text { Rank }\end{array}$ & Alternative & Weight & Rank \\
\hline \multirow{12}{*}{ Technical factor } & \multirow{12}{*}{0.512} & \multirow{12}{*}{1} & \multirow{3}{*}{$\begin{array}{l}\text { Technical } \\
\text { excellence }\end{array}$} & \multirow{3}{*}{0.628} & \multirow{3}{*}{1} & \multirow{3}{*}{0.321} & \multirow{3}{*}{1} & STS & 0.478 & 1 \\
\hline & & & & & & & & TTS & 0.257 & 3 \\
\hline & & & & & & & & PTS & 0.264 & 2 \\
\hline & & & \multirow{3}{*}{$\begin{array}{l}\text { Technical } \\
\text { versatility }\end{array}$} & \multirow{3}{*}{0.136} & \multirow{3}{*}{4} & \multirow{3}{*}{0.07} & \multirow{3}{*}{8} & STS & 0.412 & 1 \\
\hline & & & & & & & & TTS & 0.369 & 2 \\
\hline & & & & & & & & PTS & 0.219 & 3 \\
\hline & & & \multirow{3}{*}{$\begin{array}{l}\text { Technical } \\
\text { reliability }\end{array}$} & \multirow{3}{*}{0.237} & \multirow{3}{*}{2} & \multirow{3}{*}{0.121} & \multirow{3}{*}{2} & STS & 0.478 & 1 \\
\hline & & & & & & & & TTS & 0.267 & 2 \\
\hline & & & & & & & & PTS & 0.254 & 3 \\
\hline & & & \multirow{3}{*}{ Subtotal } & & & & & STS & 0.469 & 1 \\
\hline & & & & & & & & TTS & 0.275 & 2 \\
\hline & & & & & & & & PTS & 0.256 & 3 \\
\hline \multirow{12}{*}{$\begin{array}{l}\text { Environmental } \\
\text { factor }\end{array}$} & \multirow{12}{*}{0.219} & \multirow{12}{*}{3} & \multirow{3}{*}{$\begin{array}{c}\text { Quay } \\
\text { environment }\end{array}$} & \multirow{3}{*}{0.380} & & & & STS & 0.348 & 2 \\
\hline & & & & & 1 & 0.083 & 5 & TTS & 0.375 & 1 \\
\hline & & & & & & & & PTS & 0.276 & 3 \\
\hline & & & & & & & & STS & 0.498 & 1 \\
\hline & & & $\begin{array}{l}\text { Legal/policy } \\
\text { environment }\end{array}$ & 0.279 & 3 & 0.061 & 9 & TTS & 0.352 & 2 \\
\hline & & & стіv & & & & & PTS & 0.150 & 3 \\
\hline & & & & & & & & STS & 0.412 & 1 \\
\hline & & & $\begin{array}{c}\text { Demand } \\
\text { environment }\end{array}$ & 0.341 & 2 & 0.075 & 6 & TTS & 0.298 & 2 \\
\hline & & & & & & & & PTS & 0.290 & 3 \\
\hline & & & & & & & & STS & 0.412 & 1 \\
\hline & & & Subtotal & & & & & TTS & 0.342 & 2 \\
\hline & & & & & & & & PTS & 0.246 & 3 \\
\hline & & & & & & & & STS & 0.439 & 1 \\
\hline & & & $\begin{array}{c}\text { Risk } \\
\text { management }\end{array}$ & 0.34 & 2 & 0.092 & 4 & TTS & 0.268 & 3 \\
\hline & & & & & & & & PTS & 0.293 & 2 \\
\hline & & & & & & & & STS & 0.450 & 1 \\
\hline & & & $\begin{array}{l}\text { Emergency } \\
\text { response }\end{array}$ & 0.394 & 1 & 0.106 & 3 & TTS & 0.326 & 2 \\
\hline Safety factor & 0.269 & 2 & & & & & & PTS & 0.223 & 3 \\
\hline & & & & & & & & STS & 0.448 & 1 \\
\hline & & & Cooperation & 0.266 & 3 & 0.072 & 7 & TTS & 0.242 & 3 \\
\hline & & & & & & & & PTS & 0.310 & 2 \\
\hline & & & & & & & & STS & 0.446 & 1 \\
\hline & & & Subtotal & & & & & TTS & 0.284 & 2 \\
\hline & & & & & & & & PTS & 0.270 & 3 \\
\hline & & & & & & & & STS & 0.440 & 1 \\
\hline & Total & & & & & & & TTS & 0.306 & 2 \\
\hline & & & & & & & & PTS & 0.253 & 3 \\
\hline
\end{tabular}


Second, in the sub-criteria, priorities were derived in the following order: technical excellence (0.628), technical reliability $(0.237)$, and technical versatility $(0.136)$ in relation to the technical factor. Among the safety factors, priorities were derived as emergency response (0.394), risk management (0.340), and cooperation (communication) capability (0.266), among which the order of importance was quay environment $(0.380)$, followed by demand environment (0.341), and legal/policy environment (0.279). It is worth noting that in terms of technical factors, the experts who participated in the survey placed the highest weight on the technical excellence of temperature and pressure control and re-liquefaction control, which has been accumulated through various pilot operations of LNG-fueled ships from the point of view of shipyard. In addition, some weights were also given to reliability aspects such as system management technology for LNG leaks and overpressures that may occur during LNG bunkering. Furthermore, experts who participated in the survey gave similar scores of importance for emergency response and risk management among the safety factors. Experts also assigned the highest priority of importance to quay environment (0.380) among environmental factors and lowest to legal/policy environment (0.279).

As shown in Table 6, in terms of the overall weight considering major factors and sub-criteria, technical excellence (0.321) and technical reliability $(0.121)$ were found to have higher relative importance among the technical factors. Among the safety factors, the weights of emergency response (0.106) and risk management (0.092) were the next highest. In addition, among environmental factors, the importance of the quay environment (0.083) was found to be the highest. The lowest weights were given to the legal/policy environment (0.061) among environmental factors, technical versatility (0.070) among technical factors, and cooperation (communication) environment (0.072) among safety factors. Examining the overall rankings alone, the 1st and 2nd highest importance are those from the technical factor, while the next two most important are those from the safety factor. The survey experts ranked the quay environment 5 th, and given that this is closely related to the technical factor, it is thought that the experts place higher weights on the importance of the technical and safety factors rather than the environmental factor, which is an external factor.

In particular, in terms of the preference of alternatives related to LNG bunkering in the shipyard, LNG bunkering with the STS method (0.440) showed the highest preference, followed by LNG bunkering with the TTS method (0.306) and with the PTS method (0.253). The STS method is the most preferred method because there is a practical limitation in constructing a separate LNG piping facility considering the characteristics of the quay environment in the shipyard. In particular, the STS method displayed the highest weight considering the preference of LNG bunkering is based on the technical, safety, and environmental factors of Hierarchy 1 (major factor), whereas most sub-factors of Hierarchy 2 (sub-criteria) showed similar preference as the overall preference. However, in the quay environment category among environmental factors, it was found that LNG bunkering of the TTS method (0.375) is preferred over that of the STS method (0.348), although this difference is small. As a result, ranking reversal paradox occurred inevitably as the AHP questionnaire analysis was conducted for experts assuming no weight to either factor among STS, TTS, or PTS [36]. However, the priority of technical factor and safety factor was the same as STS $>$ TTS $>$ PTS, and only environment factor had a priority order of TTS $>$ STS $>$ PTS. The reason is that, in the case of a pile-type quay, the TTS method is preferred because there is a problem in terms of safe mooring with the STS method due to double banking. In the technical excellence factor among the technical factors and risk management and cooperation factors among the safety factors, the second highest preference after STS-type LNG bunkering (0.440) was PTS-type LNG bunkering (0.253), rather than TTS-type LNG bunkering (0.306).

\section{Discussion}

In this study, it was confirmed through a literature review that the emissions of petroleum fuels caused severe damage to human health and global environment. Among 
various alternatives for reducing air pollutants in the international shipping sector, the introduction of LNG-fueled ships is gaining attention as the most efficient method, and LNG bunkering infrastructure to supply LNG fuel to ships in major ports across the globe has been constructed and operated in some cases. In line with these changes, multiple trial operations to introduce the LNG bunkering industry in South Korea are underway, and a range of LNG bunkering methods were examined through analysis of previous studies and literature review to derive the optimal method for LNG bunkering in shipyards. Most of the prior studies have focused on issues related to the growth potential of the LNG bunkering industry in accordance with the IMO 2020 environmental regulation, risks and responsive actions during LNG bunkering operations, and the supply and demand following the expansion of LNG bunkering-related infrastructure; the significance of this study lies in that by adopting the AHP method, survey results of experts engaged in the relevant industries were analyzed in depth. Based on the results, the relative importance and priorities of the optimal LNG bunkering method were derived.

According to the priority of the optimal LNG bunkering method in the shipyard, the derived preference was in the order of the STS method, TTS method, and the PTS method as mentioned Figure 2. For overcoming the limitations of the successful empirical test of LNG transfer in a South Korean shipyard, the results are indicated on the arrangement diagram of shipyard " $\mathrm{D}$ " as can be seen in Figure 5. From this diagram, the safest quay adjacent to the outer port and a jetty-type quay were designated with the STS method, and the safest quay to which an LNG storage truck can have access to was designated with the TTS method. In addition, the quay that can stably install pipes to a jetty-type quay was designated with PTS method, and relative priorities were indicated in the diagram.

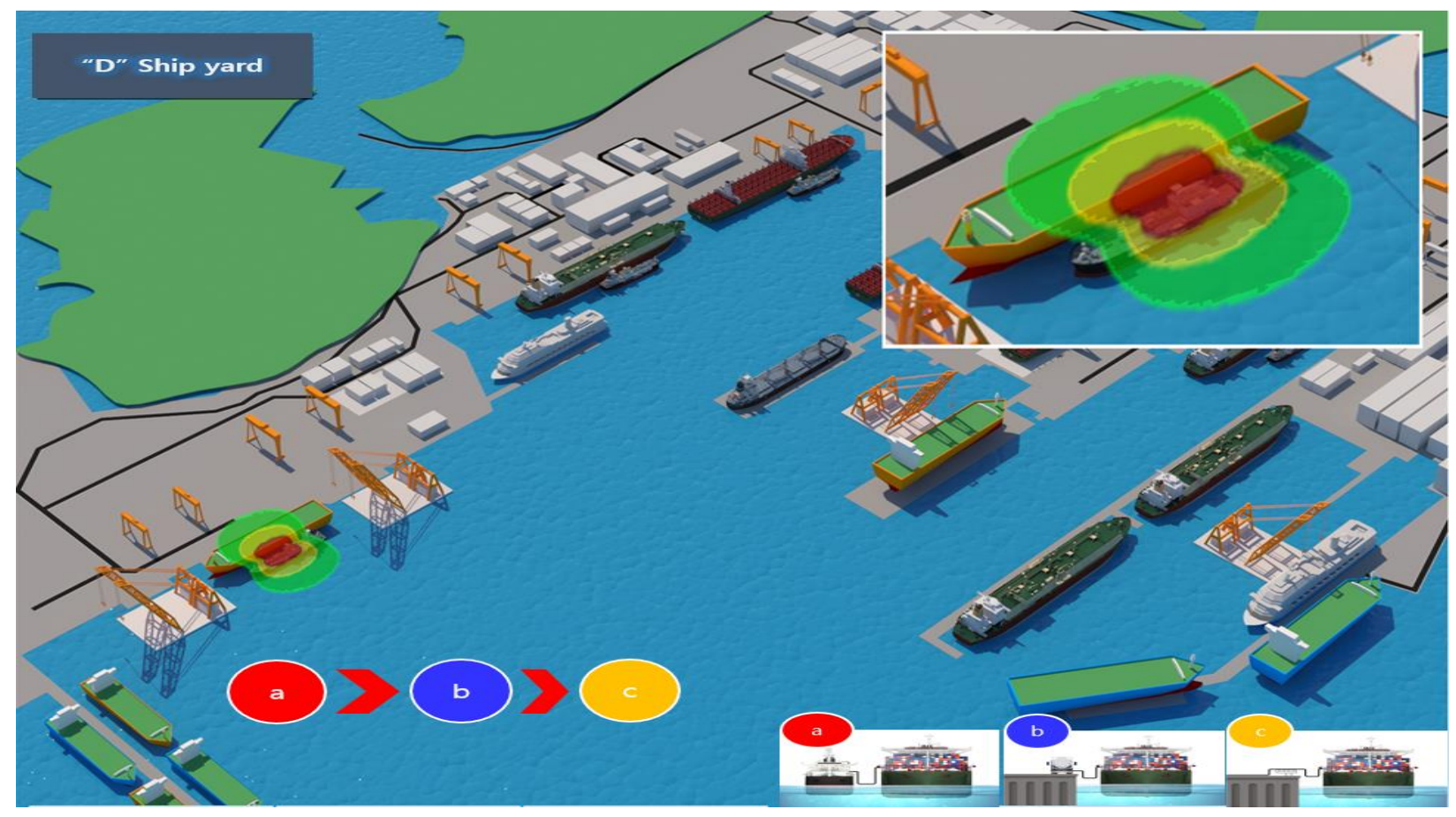

Figure 5. LNG bunkering arrangement diagram in shipyard “ $\mathrm{D}$ ” considering the priority of LNG bunkering method.

In this study, for selecting LNG bunkering methods in a shipyard considering various interests involved in the decision making, expert groups were categorized into shipyard owners, registers of shipping, ship owners, universities, governmental agencies, and research institutes, thereby inducing objective evaluation to derive conclusions under multi-criteria and multi-attribute environments. However, a practical limitation in ensuring a completely objective evaluation with the participating experts arises due to difficulties in achieving face-to-face interaction because of restrictions under the COVID-19 pandemic 
and owing to varying levels of understanding of the explanation provided. In other words, the experts have already established self-criteria and judgments with bias for the selected alternatives, thereby leading to limitations in ensuring the integrity of the objective evaluation. Nevertheless, this study is significant in that a reference framework was developed to facilitate objective decision-making through pairwise comparison of AHP on the issue of LNG bunkering in a shipyard; this is the first study to do so in this field. Finally, considering that the proposed reference framework resulted in a complete arrangement diagram of LNG bunkering in shipyard " $\mathrm{D}$ " by taking into account the priorities of LNG bunkering methods discussed in the results, we can observe that AHP is a suitable method for objective evaluation. Nevertheless, for shipyards in South Korea, more in-depth investigation is required on the suitability of the STS, TTS, and PTS methods by verifying safety through various simulations of LNG leaks, advancement of work procedures through registers of shipping, promotion of institutionalization through cooperation with local communities and the government, and designation of a quay dedicated to LNG bunkering with ensured safety. TTS-type LNG bunkering is being carried out at a few in ports of South Korea, and thus an optimal method must be derived by utilizing AHP, an objective decision-making method, centered on shipyards that will make it possible to apply the most diverse LNG bunkering methods in the future. The conditions of individual quays in a shipyard are quite diverse, and the quay type varies according to caisson, cell block, sheet file, dolphin, etc. Therefore, no matter how much the result of AHP is used to prioritize, results can be derived with little differences among STS, TTS, and PTS. Therefore, determining the highest values for the results among STS, TTS, and PTS is necessary by specifying the second values for sub-value in order to acknowledge the relativity of the contextual condition values. This study used AHP as a decision-making tool for evaluating the survey responses of 38 professionals from diverse backgrounds; however, the scope of analysis was limited. Nevertheless, the results are expected to contribute as underlying data required for the expansion of domestic ports in the future.

\section{Conclusions}

Using AHP, an optimization method of decision-making, centering on an expert group including shipyard owners, shipbuilders, ship owners, the government, universities, and research institutes, the order of preference for the LNG bunkering methods was STS method $(0.440)>$ TTS method (0.306) > PTS method (0.253). However, South Korea has not yet established a free market entry for LNG bunkering at the private sector level, allowing LNG transactions between parties involved in the business, deregulation of the control of LNG volume and prices, and safety procedures and regulations for LNG bunkering, as in the case of the Port of Rotterdam in Europe and the Port of Yokohama in Japan; thus, there are limitations in applying LNG bunkering in general ports and shipyards. In other words, we used AHP techniques to derive optimal LNG bunkering methods applicable to shipyards. There is a limitation, however, of research on LNG bunkering that will be frequently carried out in port for the future.

Therefore, based on technical collaboration with shipyards that receive several LNGfueled ship orders, the South Korean government must benchmark successful cases of Japan and establish a cooperative network that engages government agencies, the financial sector, shipyards, shippers, port authorities, shipping companies, and register of shipping and play a leading role in promoting technology development and commercialization in relation to LNG bunkering. In addition, universities and research institutes related to LNG bunkering should cooperate with shipyards to conduct R\&D on technology development, manage patents and intellectual property rights, standardize technology and procedures, and institutionalize related systems and laws. In addition, centering on the Korea Offshore and Shipbuilding Association, on the basis of lessons learned from the demonstration test of LNG transfer with the STS method, which is the first successful case in a shipyard (shipyard " $\mathrm{D}$ " in South Korea), the competitiveness of pilot operations in shipyards needs to be enhanced following increased orders of LNG-fueled ships. Based on this enhance- 
ment, stakeholders in LNG bunkering in South Korea should (1) establish and consolidate LNG bunkering cluster networks, (2) analyze key factors of support for the promotion of smooth implementation of LNG bunkering in ports, (3) identify priorities of quantitative indicators according to suitability (4) promote LNG bunkering test and verification. Thus, research on the development of an advanced optimized evaluation model for optimized LNG bunkering in ports can be continued. To derive this model using the process of aggregative score calculation, the optimal result will be derived by indexation. This index is based on relative or absolute weights of factors such as "port", "freight", "ship", and "LNG bunkering".

Author Contributions: Conceptualization: Y.-G.L.; methodology: C.-H.L.; validation C.-H.L.; investigation: C.-H.L.; resources: C.-H.L.; data curation: J.-K.K.; writing-original draft preparation, Y.-G.L.; writing-review and editing, C.-H.L.; supervision, C.-H.L.; project administration: J.-K.K.; funding acquisition, C.-H.L. All authors have read and agreed to the published version of the manuscript.

Funding: This work was supported by a grant from the National R\&D Project, "Development of LNG Bunkering Operation Technologies based on Operation System and Risk Assessment", funded by the Ministry of Oceans and Fisheries, South Korea, grant number PMS4310.

Institutional Review Board Statement: Not applicable.

Informed Consent Statement: Not applicable.

Data Availability Statement: Not applicable.

Acknowledgments: All the support is gratefully acknowledged.

Conflicts of Interest: The authors declare no conflict of interest. The funders had no role in the study design; in the collection, analyses, or interpretation of data; in the writing of the manuscript; or in the decision to publish the results.

\section{References}

1. Byrnes, T.A.; Dunn, R.J.K. Boating- and Shipping-Related Environmental Impacts and Example Management Measures: A Review. J. Mar. Sci. Eng. 2020, 8, 908. [CrossRef]

2. Brenna, M.; Bucci, V.; Falvo, M.C.; Foiadelli, F.; Ruvio, A.; Sulligoi, G.; Vicenzutti, A. A Review on Energy Efficiency in Three Transportation Sectors: Railways, Electrical Vehicles and Marine. Energies 2020, 13, 2378. [CrossRef]

3. Winnes, H.; Fridell, E.; Moldanová, J. Effects of Marine Exhaust Gas Scrubbers on Gas and Particle Emissions. J. Mar. Sci. Eng. 2020, 8, 299. [CrossRef]

4. Shipping Companies Banking on Gas Carriers as LNG Demand Grows. Available online: https://www.wsj.com/articles/ shipping-companies-banking-on-gas-carriers-as-lng-demand-grows-11552555800 (accessed on 31 January 2021).

5. Shipowner Confidence in LNG as a Marine Fuel 'Improving'. Available online: https: / lloydslist.maritimeintelligence.informa. com/LL1134706/Shipowner-confidence-in-LNG-as-a-marine-fuel-improving (accessed on 30 January 2021).

6. Lim, K.G.; Lim, M. Financial performance of shipping firms that increase LNG carriers and the support of eco-innovation. J. Ship. Trade 2020, 5, 5. [CrossRef]

7. Park, N.K.; Park, S.K. A Study on the Estimation of Facilities in LNG Bunkering Terminal by Simulation-Busan Port Case. J. Mar Sci. Eng. 2019, 7, 354. [CrossRef]

8. Lee, H.; Choi, J.; Jung, I.; Lee, S.; Yoon, S.; Ryu, B.; Kang, H. Effect of Parameters on Vapor Generation in Ship-to-Ship Liquefied Natural Gas Bunkering. Appl. Sci. 2020, 10, 6861. [CrossRef]

9. Lee, S.Y.; Chang, D. Design of Pile-Guide Mooring System for Offshore LNG Bunkering Terminal: A Case Study for Singapore Port. J. Ocean Eng. Technol. 2017, 31, 379-387. [CrossRef]

10. Lowell, D.; Wang, H.; Lutsey, N. Assessment of the Fuel Cycle Impact of Liquefied Natural Gas as Used in International Ship-Ping, ICCT. 2013; pp. 11-12. Available online: https://theicct.org/sites/default/files/publications/ICCTwhitepaper_MarineLNG_13 0513.pdf (accessed on 31 January 2021).

11. Available online: https://www.mlit.go.jp/common/001173461.pdf (accessed on 31 January 2021).

12. Ung, Y.Y.; Ho, P.S.; Ho, J.D.; Hee, L.C. Improving Liquefied Natural Gas Bunkering in Korea Through the Chinese and Japanese Experiences. Sustainability 2020, 12, 9585. [CrossRef]

13. KAGUYA LNG Tanker. Available online: https://www.marinetraffic.com/en/ais/details/ships/shipid:6347651/mmsi:43101568 7/imo:9862293/vessel:KAGUYA (accessed on 31 January 2021).

14. Available online: https:/ / central-lng.com/en/news/kaguya-conducts-ship-to-ship-lng-bunkering-to-a-k-line-new-buildingcar-carrier/ (accessed on 31 January 2021). 
15. Lee, T.; Nam, H. A Study on Green Shipping in Major Countries: In the View of Shipyards, Shipping Companies, Ports, and Policies. Asian J. Ship. Logist. 2017, 33, 253-262. [CrossRef]

16. Chun, J.M.; Kang, H.K.; Kim, Y.T.; Jung, M.H.; Cho, K.H. Case study on operating characteristics of gas fueled ship under the conditions of load variation. J. Korean Soc. Mar. Eng. 2016, 40, 447-452. [CrossRef]

17. Lee, J.H.; Woo, J. Green New Deal Policy of South Korea: Policy Innovation for a Sustainability Transition. Sustainability 2020, 12, 191. [CrossRef]

18. DSME, KR Complete World's First Ship-to-Ship LNG Bunkering Trial. Available online: https:/ /www.seatrade-maritime.com/ bunkering/dsme-kr-complete-worlds-first-ship-ship-lng-bunkering-trial (accessed on 31 January 2021).

19. Kim, H.S.; Choi, K.H. A study on the development and operation of LNG Hub Port in Korea. Korean Int. Commer. Rev. 2018, 33, 335-352.

20. SM JEJU LNG2. Available online: https://www.vesselfinder.com/vessels/SM-JEJU-LNG2-IMO-9830757-MMSI-374333000 (accessed on 31 January 2021).

21. Laribi, S.; Guy, E. Promoting LNG as A Marine Fuel in Norway: Reflections on the Role of Global Regulations on Local Transition Niches. Sustainability 2020, 12, 9476. [CrossRef]

22. Kim, K.; Park, K.; Roh, G.; Chun, K. Case Study on Boil-Off Gas (BOG) Minimization for LNG Bunkering Vessel Using Energy Storage System (ESS). J. Mar. Sci. Eng. 2019, 7, 130. [CrossRef]

23. Sun, W.; Hu, Q.; Hu, S.; Su, J.; Xu, J.; Wei, J.; Huang, G. Numerical Analysis of Full-Scale Ship Self-Propulsion Performance with Direct Comparison to Statistical Sea Trail Results. J. Mar. Sci. Eng. 2020, 8, 24. [CrossRef]

24. Xuan, S.; Hu, S.; Li, Z.; Li, W.; Li, B. Dynamics Simulation for Process Risk Evolution on the Bunker Operation of an LNG-fueled Vessel with Catastrophe Mathematical Models. J. Mar. Sci. Eng. 2019, 7, 299. [CrossRef]

25. Vidmar, P.; Perkovičc, M.; Gucma, L.; Łazuga, K. Risk Assessment of Moored and Passing Ships. Appl. Sci. 2020, 10, 6825. [CrossRef]

26. Sánchez-Lozano, J.M.; Salmerón-Vera, F.J.; Ros-Casajús, C. Prioritization of Cartagena Coastal Military Batteries to Transform Them into Scientific, Tourist and Cultural Places of Interest: A GIS-MCDM Approach. Sustainability 2020, 12, 9908. [CrossRef]

27. MacKinnon, W.J. Development of the SPAN Technique for Making Decisions in Human Groups. Am. Behav. Sci. 1996, 9, 9-13. [CrossRef]

28. Hong, S.; Choi, B.; Lee, D.; Lee, J.; Park, S. An evaluation of the weights and investigation of the impact factors for supplying LNG. Trans. Korean Hydrog. New Energy Soc. 2009, 20, 79-85.

29. Saaty, T.L. A scaling method for priorities in hierarchical structures. J. Math. Psychol. 1977, 11, 234-281. [CrossRef]

30. Salabun, W.; Wątróbski, J.; Shekhovtsov, A. Are MCDA Methods Benchmarkable? A Comparative Study of TOPSIS, VIKOR, COPRAS, and PROMETHEE II Methods. Symmetry 2020, 12, 1549. [CrossRef]

31. Tian, G.; Zhang, H.; Zhou, M.C.; Li, Z. AHP, gray correlation, and TOPSIS combined approach to green performance evalu-ation of design alternatives. IEEE Trans. Syst. Man Cybern. Syst. 2018, 48, 1093-1105. [CrossRef]

32. Park, S.-B.; Sim, M.-J.; Kim, M.-S.; Kim, J.-H.; Lee, J.-M. A Study of Thermo-Mechanical Analysis for the Design of High Pressure Piping System for Natural Gas Fuel Vessel. J. Korean Soc. Mar. Eng. 2015, 39, 425-431. [CrossRef]

33. Lee, H. Strategies for Improving the Competitiveness of the Korean Shipbuilding Industry: Case Study of Hyundai Heavy In-dustries. Master's Thesis, World Maritime University, Malmö, Sweden, 2015.

34. Joe, T.; Chang, H. A Study on User-Oriented and Intelligent Service Design in Sustainable Computing: A Case of Shipbuilding Industry Safety. Sustainability 2017, 9, 544. [CrossRef]

35. Shao, Y.; Lee, Y.; Kang, H. Dynamic Optimization of Boil-Off Gas Generation for Different Time Limits in Liquid Natural Gas Bunkering. Energies 2019, 12, 1130. [CrossRef]

36. Sałabun, W.; Ziemba, P.; Watróbski, J. The Rank Reversals Paradox in Management Decisions: The Comparison of the AHP and COMET Methods. In Intelligent Decision Technologies 2016. IDT 2016. Smart Innovation, Systems and Technologies; Czarnowski, I., Caballero, A., Howlett, R., Jain, L., Eds.; Springer: Berlin/Heidelberg, Germany, 2016; Volume 56. [CrossRef] 